\title{
SOIL MOISTURE ANALYSIS USING MULTISPECTRAL DATA IN NORTH CENTRAL PART OF MONGOLIA
}

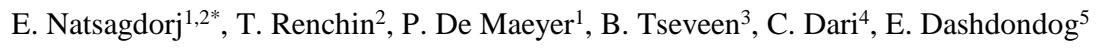 \\ ${ }^{1}$ Dept. of Geography, Faculty of Science, Ghent University, 9000 Ghent, Belgium - \\ enkhjargal.natsagdorj@ugent.be; Philippe.DeMaeyer@UGent.be \\ ${ }^{2}$ NUM-ITC-UNESCO Laboratory for Space Science and Remote Sensing, National University of Mongolia, Ulaanbaatar, Mongolia \\ - enkhjargal_spe@num.edu.mn; tsolmon@num.edu.mn \\ ${ }^{3}$ Dept. of Environment and Forest Engineering, National University of Mongolia, Ulaanbaatar, Mongolia - \\ batchuluun@num.edu.mn \\ ${ }^{4}$ Dept. of Management, School of Business, National University of Mongolia, Ulaanbaatar, Mongolia - dchimgee@ num.edu.mn \\ ${ }^{5}$ Dept. of Physics, School of Arts and Sciences, National University of Mongolia, Ulaanbaatar, Mongolia - erdenebtr@gmail.com
}

\section{Commission, WG VI/4}

KEY WORDS: Soil moisture, satellite, modelling, ground truth measurement, moisture index

\begin{abstract}
:
Soil moisture (SM) content is one of the most important environmental variables in relation to land surface climatology, hydrology, and ecology. Long-term SM data-sets on a regional scale provide reasonable information about climate change and global warming specific regions. The aim of this research work is to develop an integrated methodology for SM of kastanozems soils using multispectral satellite data. The study area is Tuv $\left(48^{\circ} 40^{\prime} 30^{\prime \prime} \mathrm{N}\right.$ and $\left.106^{\circ} 15^{\prime} 55^{\prime \prime} \mathrm{E}\right)$ province in the forest steppe zones in Mongolia. In addition to this, land surface temperature (LST) and normalized difference vegetation index (NDVI) from Landsat satellite images were integrated for the assessment. Furthermore, we used a digital elevation model (DEM) from ASTER satellite image with 30-m resolution. Aspect and slope maps were derived from this DEM. The soil moisture index (SMI) was obtained using spectral information from Landsat satellite data. We used regression analysis to develop the model. The model shows how SMI from satellite depends on LST, NDVI, DEM, Slope, and Aspect in the agricultural area. The results of the model were correlated with the ground SM data in Tuv province. The results indicate that there is a good agreement between output SM and SM of ground truth for agricultural area. Further research is focused on moisture mapping for different natural zones in Mongolia. The innovative part of this research is to estimate SM using drivers which are vegetation, land surface temperature, elevation, aspect, and slope in the forested steppe area. This integrative methodology can be applied for different regions with forest and desert steppe zones.
\end{abstract}

\section{INTRODUCTION}

Soil moisture (SM) presents an important environmental indicator controlling and regulating the interaction between the atmosphere and the land surface. Furthermore, SM regulates the ratio of runoff and infiltration and controls major energy fluxes. Moreover, SM is also an important factor in plant productivity and it has direct influence on crop productivity. Therefore, the distribution of SM in the landscape, both spatial and temporal, is a key variable of climate system modelling. SM is one of the most important environmental variables in the relation to land surface climatology, hydrology and ecology. In face of the importance of SM, its spatial and temporal assessment is difficult. The standard procedure for SM assessment against all other SM-methods are calibrated the gravimetric method from soil probes in the field. This standard procedure is typically a point measurement. Because of local scale variations in soil properties, terrain (slope, exposition), and vegetation cover the derivation of representative SM-distributions in the field sites is very difficult. Furthermore, field methods are labor intensive, expensive, and sometimes difficult to undertake in the Mongolian landscape. The most accurate method to estimate $\mathrm{SM}$ is gravimetric sampling as mentioned above. The soil sample from the field has to be immediately measured by putting the sample for 24 to $48 \mathrm{~h}$ in a drying oven at $105^{\circ} \mathrm{C}$, to measure the mass of the dry soil. Further soil bulk densities are required to convert gravimetric (water mass per soil mass) to volumetric values (water volume per soil volume). A comprehensive review about various SMC-methods is presented (Verstraeten, Veroustraete, and Feyen, 2008). In contrast with the previous, remote sensing (RS) techniques which are combined with additional GIS-data are effective because of their spatially aggregated data assessment. By nature, SM is a very heterogeneous variable and varies on small scales with soil properties and drainage patterns. Therefore, information about soil types, soil properties and terrain are important. Satellite measurements integrate over relative largescale areas, with the presence of vegetation adding complexity to the interpretation. The annual evaporation is $150 \sim 250 \mathrm{~mm}$ in the steppe zone and over $150 \mathrm{~mm}$ in desert steppe and deserted zones. There is SM decrease from north to south (Tsoozol et al., 2008).

The Mongolian horizontal zone is clearly represented in the central comparatively plain part of Mongolia, where the zone of kastanozems soils are divided into three subzones (dark kastanozem, kastanozem, and light kastanozem) (Dorjgotov, 2003). Remote sensing and GIS provide excellent tools for monitoring suitability for development of agriculture land in Mongolia (Ghar et al., 2005). Understanding the spatial and temporal variability of moisture patterns is critically important for food security in Mongolia, and other regions of central Asia. For this reason, it is essential to make research on SM and other suitable drivers for development of agricultural land in Mongolia. This research focused on developing a model for

\footnotetext{
${ }^{*}$ Corresponding author
} 
estimation of SM using satellite and ground truth for kastanozems soils. The kastanozems soil is the common type in Mongolia.

Many soil studies used only index, wetness index and point measurement from station. For example, Mohamed used the normalized day-night surface temperature difference index (NTDI) with moisture availability $\left(m_{a}\right)$ over Mongolian Steppe during the growing season, and showed a significant inverse exponential correlation with $m_{a}$. This result indicates that the NTDI is useful as a surrogate of moisture availability in the steppe terrain of central Asia (Mohamed and Kimura, 2014). Cornicka et al., (2003) developed the approach and compared results with other methods of selecting moisture reference years for hydrothermal simulations. They used climate stations' data for their model (Cornicka, Djebbar, and Dalgliesh 2003; Attorre et al. 2007) determined the moisture index using precipitation and potential evapotranspiration. The moisture index, related to the potential amount of available precipitation, was the most important factor explaining the distribution of Dracaena Cinnabari. Information of climate change and SM from special sensor microwave/imager (SSM/I) was used for African continent ( $\mathrm{Lu}$ et al., 2013). They concluded that such information is useful in climate change study, but it is only at point scale and is only available at limited locations.

The innovation part of our research is to consider elevation slope and aspects with other environmental drivers in forested mountain and agricultural areas for soil estimation. The elevation, slope and aspect were applied for this methodology which have not been considered in previous studies.

Mongolia also needs satellite image processing for the SM analysis. It will be useful for agriculture and pastureland. This paper proposes that it is important to consider elevation, slope, and aspect for SM in mountainous areas.

\section{STUDY AREA AND USED MATERIALS}

\subsection{Study area}

The study area is Bornuur soum from the central agricultural area in Tuv province $\left(48^{\circ} 40^{\prime} 30^{\prime \prime} \mathrm{N}, 106^{\circ} 15^{\prime} 55^{\prime} \mathrm{E}\right)$ and located in the forest steppe zone (Figure 1). Four different soil types: kastanozems, greysols, leptosols, cambilsols dominate in Bornuur (Dorjgotov, 2003). Precipitation is 200 300 mm/year and elevation of the study area is $872 \sim 1821 \mathrm{~m}$. Bornuur is one of the crop areas in Mongolia. The dominate plants are allium Mongolicum, Iris potaninii, Patriniasibirica and Scutellariabaicalensis (Bayartogtokh et al., 2015).

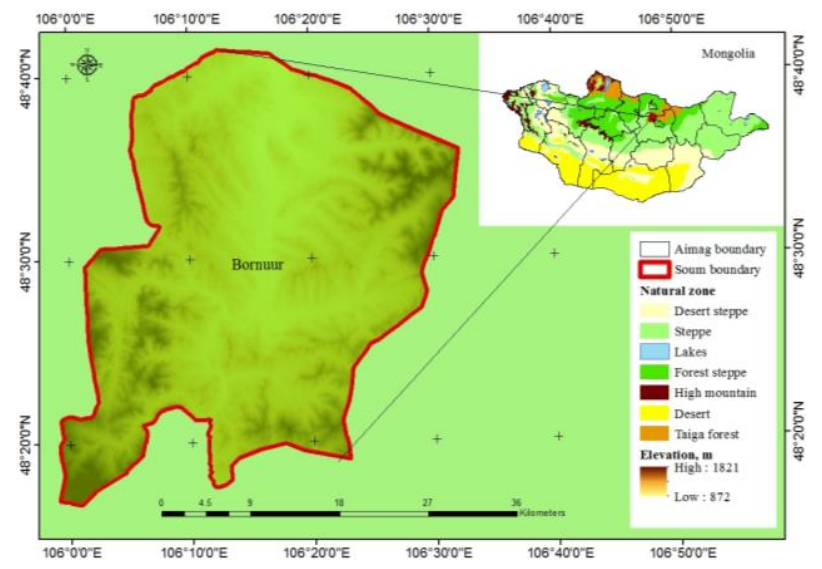

Figure 1. Study area (Bornuur soum in Tuv province in Mongolia)
The thematic soil map with four types of soils and color combination bands 5, 4 and 3 from ETM (Figure 2) was used for the comparison in the research. The kastanozems soils from the study area were investigated for the SM analysis.

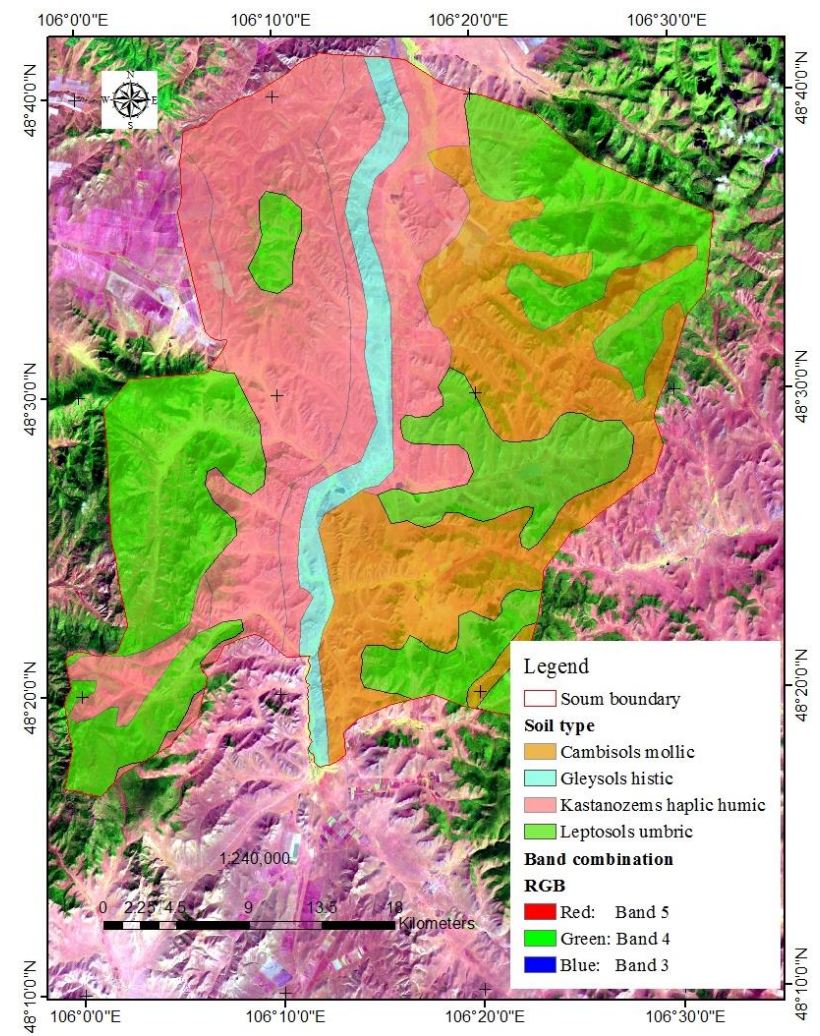

Figure 2. Color composite image from Landsat +ETM bands which are 5, 4 and 3 and thematic soil map (source: Institute of Geography, Mongolian Academy of Science).

\subsection{Datasets}

2.2.1 Landsat ETM+ \& OLI8 satellite data: Landsat 7 enhanced thematic mapper (ETM) image (19 September 2011, path 132, row 26) was downloaded from the USGS earth resource observation and science center (EROS) website, and applied for this research. Landsat ETM+ has a strip. We used Landsat gapfill method to remove the strips (http://glovis.usgs.gov/).

2.2.2 ASTER satellite data: In order to develop elevation, aspect, slope we used advanced spaceborne thermal emission and reflection radiometer (ASTER) satellite, global digital elevation model (GDEM) data with $30 \mathrm{~m}$ resolution. The ASTER GDEM covers land surfaces between $83^{\circ} \mathrm{N}$ and $83^{\circ} \mathrm{S}$, and is composed of $22,6001^{\circ}$-by- $1^{\circ}$ tiles. The ASTER GDEM is in GeoTIFF format with geographic lat/long coordinates and a 1 arc-second $(30 \mathrm{~m})$ grid of elevation postings. It is referenced to the WGS84/EGM96 geoid. Pre-production estimated accuracies for this global product were $20 \mathrm{~m}$ at $95 \%$ confidence for vertical data and $30 \mathrm{~m}$ at $95 \%$ confidence for horizontal data (http://gdem.ersdac.jspacesystems.or.jp/). 
2.2.3 Ground truth data: SM data was collected during the field trips in Bornuur, Tuv province using traditional method. We took soil samples from the depth $0 \sim 50 \mathrm{~cm}$ in September 2011 (Table 1, all the corresponding soil types are kastanozems). Traditional method was developed in the following way. First, we collected soil sample data in the study area and found its weight. Next is to dry soil. Traditional method allowed us to measure amount of moisture using dried soil samples (Equation 1).

$$
W=(a \cdot 100) / b
$$

where $\quad W$ is the SM from traditional method; $a$ is the amount of water in soil; $b$ is the dried soil.

\begin{tabular}{cccccc}
\hline Latitude & Longitude & $\begin{array}{c}\text { Acquired } \\
\text { date }\end{array}$ & & SM & \\
\hline & & & $(\%)$ & $(\mathrm{g})$ & $(\mathrm{mm})$ \\
\hline $48^{\circ} 37^{\prime} 43.68^{\prime \prime}$ & $106^{\circ} 09^{\prime} 11.88^{\prime \prime}$ & $9 / 20 / 2011$ & 5.6153 & 7.6299 & 9.474 \\
$48^{\circ} 37^{\prime} 45.12^{\prime \prime}$ & $106^{\circ} 09^{\prime} 14.76^{\prime \prime}$ & $9 / 20 / 2011$ & 5.7114 & 10.3022 & 8.609 \\
$48^{\circ} 37^{\prime} 46.56^{\prime \prime}$ & $106^{\circ} 09^{\prime} 16.92^{\prime \prime}$ & $9 / 20 / 2011$ & 5.9329 & 7.9736 & 9.238 \\
$48^{\circ} 36^{\prime} 52.56^{\prime \prime}$ & $106^{\circ} 06^{\prime} 52.56^{\prime \prime}$ & $9 / 20 / 2011$ & 7.0703 & 6.4935 & 8.446 \\
$48^{\circ} 36^{\prime} 50.04^{\prime \prime}$ & $106^{\circ} 06^{\prime} 50.04^{\prime \prime}$ & $9 / 20 / 2011$ & 7.3942 & 6.5171 & 10.313 \\
$48^{\circ} 36^{\prime} 52.56^{\prime \prime}$ & $106^{\circ} 06^{\prime} 47.16^{\prime \prime}$ & $9 / 20 / 2011$ & 3.4012 & 5.4895 & 7.651 \\
$48^{\circ} 40^{\prime} 49.08^{\prime \prime}$ & $106^{\circ} 16^{\prime} 23.52^{\prime \prime}$ & $9 / 19 / 2011$ & 2.6161 & 7.8169 & 7.947 \\
$48^{\circ} 40^{\prime} 49.08^{\prime \prime}$ & $106^{\circ} 16^{\prime} 28.56^{\prime \prime}$ & $9 / 19 / 2011$ & 2.4655 & 7.1989 & 10.103 \\
$48^{\circ} 40^{\prime} 50.16^{\prime \prime}$ & $106^{\circ} 16^{\prime} 32.88^{\prime \prime}$ & $9 / 19 / 2011$ & 2.1816 & 9.3878 & 11.635 \\
$48^{\circ} 40^{\prime} 44.04 "$ & $106^{\circ} 16^{\prime} 24.06^{\prime \prime}$ & $9 / 19 / 2011$ & 2.1605 & 8.8401 & 12.275 \\
$48^{\circ} 40^{\prime} 45.48^{\prime \prime}$ & $106^{\circ} 16^{\prime} 28.92^{\prime \prime}$ & $9 / 19 / 2011$ & 2.2932 & 8.2269 & 10.841 \\
$48^{\circ} 40^{\prime} 45.84^{\prime \prime}$ & $106^{\circ} 16^{\prime} 31.08^{\prime \prime}$ & $9 / 19 / 2011$ & 2.2607 & 8.6510 & 9.084 \\
\hline
\end{tabular}

Table 1. Ground truth measurement in Bornuur soum, 18 20 Sept. 2011

\section{INTEGRATION METHOD FOR SOIL MOISTURE ANALYSIS}

The Equation (2) is used as atmospheric correction for the images in this research (Chavez, 1996). The correction map is in Figure 2.

$$
R E F=\frac{\pi \cdot(\text { Lsat }- \text { Lhaze })}{T A U v \cdot(\text { Eo } \cdot \operatorname{Cos}(\text { TZ }) \cdot T A U z+\text { Edown })}
$$

where:

$R E F$ is the spectral reflectance of the surface;

Lsat is the satellite spectral radiance for given spectral bands;

Lhaze is the upwelling spectral radiance (path radiance), value derived from image using darkobject criteria; calculated by using the dark object criteria (lowest value at the base of the slope of the histogram from either the blue or green band);

$T A U v$ is the atmospheric transmittance along the path from ground to sensor, assumed to be 1 because of nadir look angle;

$E o$ is the solar spectral irradiance;

$T Z$ is the solar zenith angle;

$T A U z$ is the atmospheric transmittance along the path from the sun to the ground surface;

Edown is the down welling spectral irradiance at the atmosphere (Chavez, 1996).

The method schema is illustrated in Figure 3.

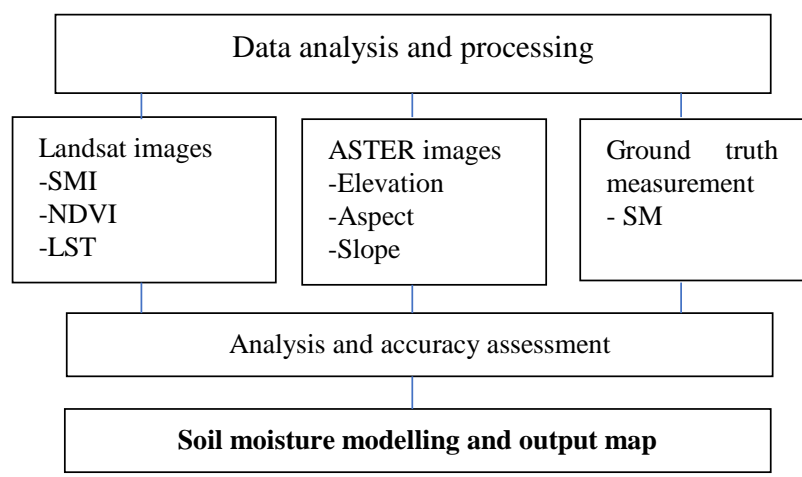

Figure 3. Method schema

SMI was calculated using the Landsat +ETM 7 bands 1 and 4 (Lewis, 1999) Equation (3) for the study area in kastanozems soil (Figure 4).

$$
S M I=\frac{N I R}{\text { VisBlue }}
$$

where $N I R$ is the near infrared channels $(0.77 \sim 0.90 \mu \mathrm{m})$; VisBlue is the visible blue channels $(0.45 \sim 0.52 \mu \mathrm{m})$.

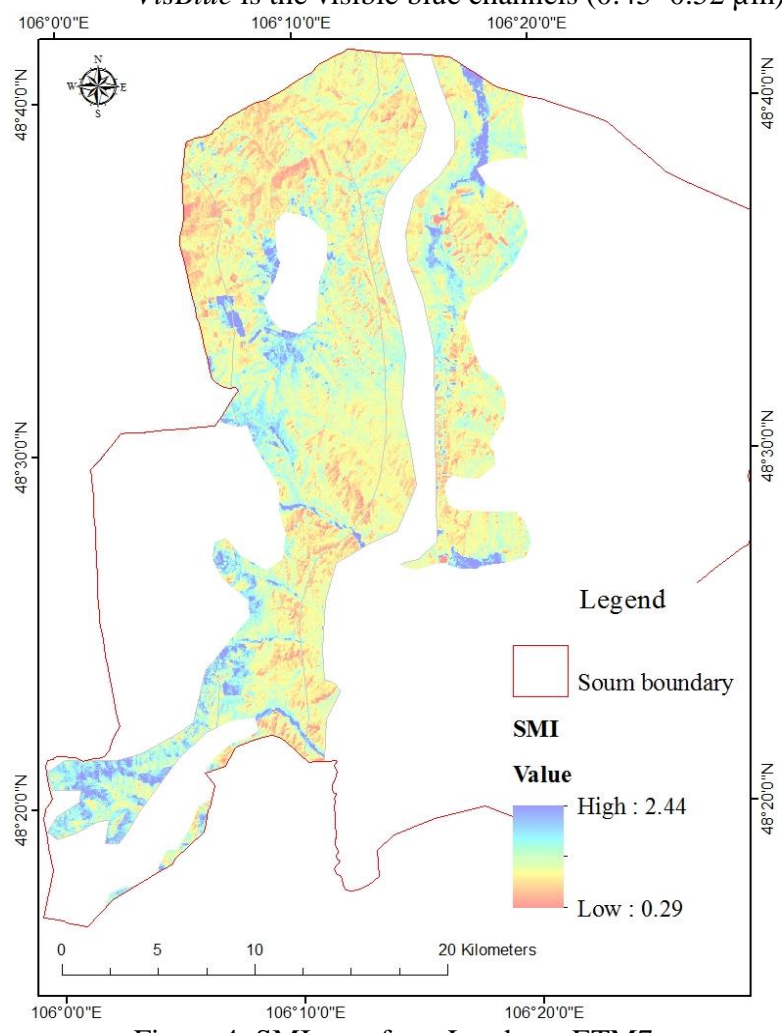

Figure 4. SMI map from Landsat +ETM7

The red (RED) and NIR channels from ETM were applied in Equation (4) for NDVI calculation (Sellers et al., 1994) (Figure $5)$

$$
N D V I=\frac{N I R-R E D}{N I R+R E D}
$$

The LST was calculated using Equation (5) by (Weng, Lu, and Schubring, 2004) (Figure 6):

$$
L S T=\left(\mathrm{BT}+w \cdot \frac{B T}{p}\right) \cdot \ln (e)
$$


where $B T$ is the satellite brightness temperature $(\mathrm{K})$;

$w$ is the wavelength of emitted radiance $(11.5 \mu \mathrm{m})$;

$p=\mathrm{h}^{*} \mathrm{c} / \mathrm{s}\left(1.438 * 10^{\wedge}-2 \mathrm{~m} \mathrm{~K}\right)$,

$h$ is the Plank's constant $\left(6.626^{*} 10^{\wedge}-34 \mathrm{Js}\right)$;

$s$ is the Boltzman constant $\left(1.38 * 10^{\wedge}-23 \mathrm{~J} / \mathrm{K}\right)$,

$c$ is the velocity of light $\left(2.998^{*} 10^{\wedge} 8 \mathrm{~m} / \mathrm{s}\right)$;

$e=0.004 * P_{v}+0.986$

$P_{v}=\left(\mathrm{NDVI}-\mathrm{NDVI}_{\min } / \mathrm{NDVI}_{\max }-\mathrm{NDVI}_{\min }\right)^{2}$ is the proportion of vegetation.

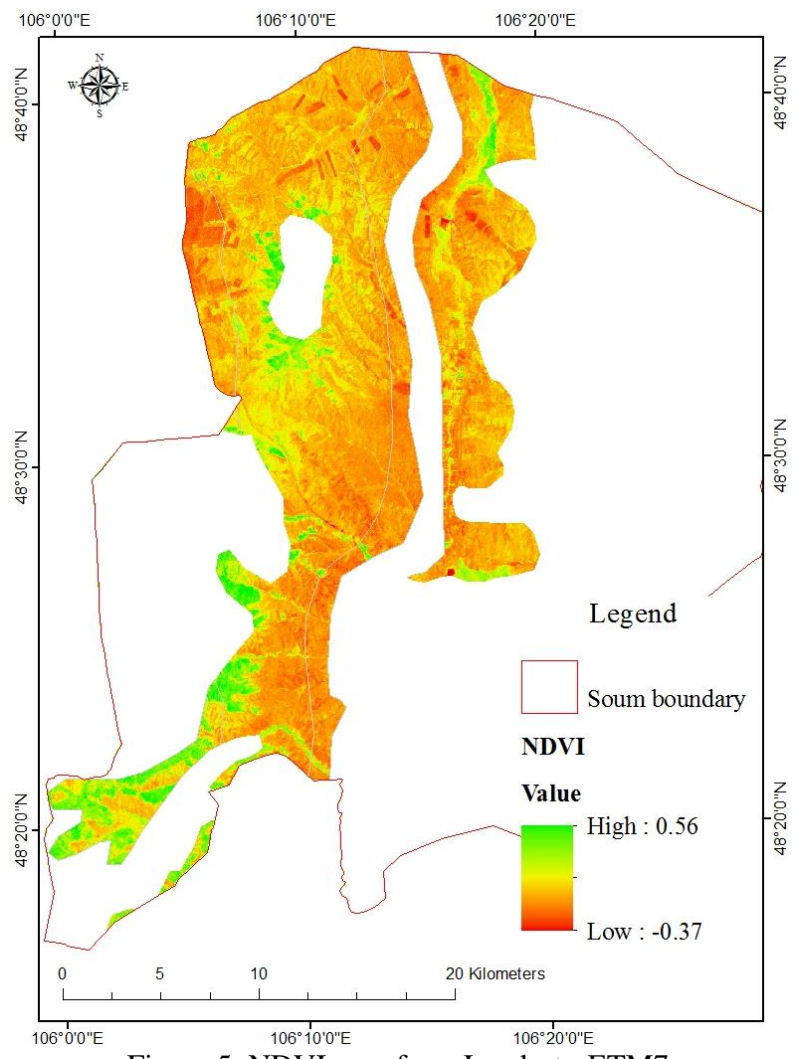

Figure 5. NDVI map from Landsat +ETM7

For elevation, aspect and slope, we used ASTER satellite, GDEM data for $30 \mathrm{~m}$ resolution. Figure 7 illustrates the elevation, aspect and slope from $30 \mathrm{~m}$ resolution from ASTER in kastanozems soil, Bornuur soum.

In order to develop the model for estimation SM we used the regression analysis. Outputs from the analysis were compared to ground truth data.

We assume SM derived from satellite and it depends on variables such as LST, NDVI, elevation, aspect and slope. F is function of dependent variables, shown as Equation (6).

$$
\text { PSMI }=F(N D V I, L S T, \text { Elevation, Aspect, Slope })
$$

Therefore, for this assumption, the multivariate regression analysis was selected. The multi-dimensional linear regression model can be described as:

$y_{i}=\beta_{0}+\beta_{1} x_{i 1}+\beta_{2} x_{i 2}+\beta_{3} x_{i 3}+\beta_{4} x_{i 4}+\beta_{5} x_{i 5}$

where $y_{i}$ is the observation variable;

$\beta_{0}$ is the intercept,

$\beta_{1} \sim \beta_{5}$ is the coefficients;

$x_{i}$ is the variables.

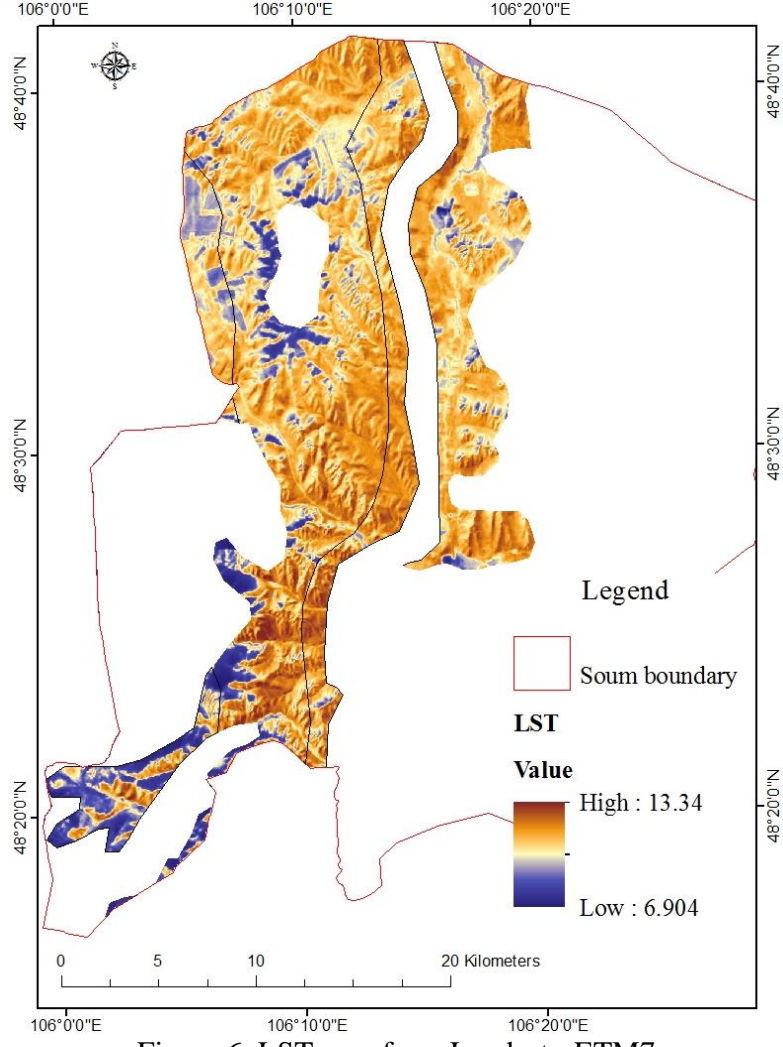

Figure 6. LST map from Landsat +ETM7

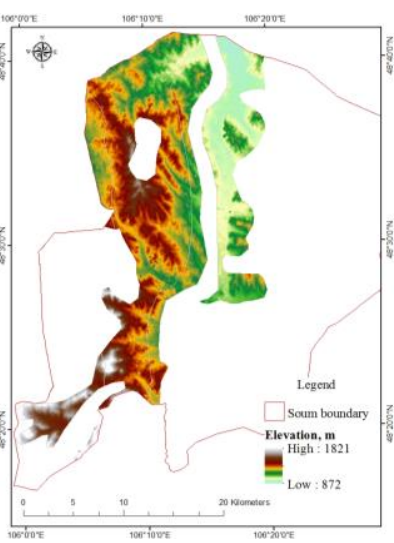

(a)

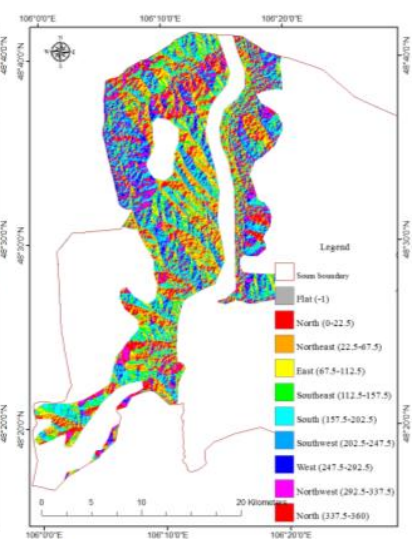

(b)

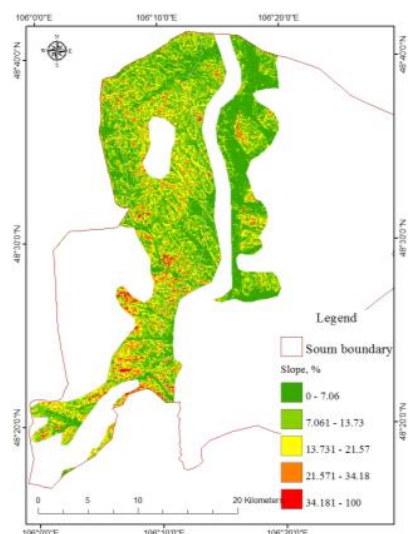

(c)

Figure 7. (a) Elevation map, (b) Aspect, (c) Slope in Bornuur soum; source: ASTER-SRTM 30 m resolution data 
Collinearity test for all variables (NDVI, LST, elevation, aspect, and slope) were estimated in table 2. B is regression coefficient of unstandardized coefficients, Std.Error is Standard error of unstandardized coefficients, Beta is beta coefficient of standardized coefficients, $t$ is $t$-statistics for the coefficients, Sig. is significance of collinearity.

In order to develop the SM model, we used multiple regression analysis (Equation (7)). The variance inflation factor (VIF) values are between 1 10, which shows that there is no multicollinearity for the regression model (Table 2). Also, correlation analysis showed that there are no strong correlations between independent variables. The independent variables are NDVI, LST, elevation, aspect and slope.

\begin{tabular}{|c|c|c|c|c|c|c|c|}
\hline \multicolumn{8}{|c|}{ Coefficients ${ }^{*}$} \\
\hline \multirow[t]{2}{*}{ Model } & \multicolumn{2}{|c|}{$\begin{array}{l}\text { Unstandardized } \\
\text { Coefficients }\end{array}$} & \multicolumn{2}{|c|}{$\begin{array}{l}\text { Standardized } \\
\text { Coefficients }\end{array}$} & \multirow[t]{2}{*}{$\mathrm{t}$} & \multirow{2}{*}{$\begin{array}{l}\text { Sig. } \\
\begin{array}{l}\text { Toler } \\
\text { ance }\end{array}\end{array}$} & \multirow{2}{*}{$\begin{array}{c}\begin{array}{c}\text { Collineari } \\
\text { ty } \\
\text { Statistics }\end{array} \\
\begin{array}{c}\text { VIF } \\
(1-10)\end{array}\end{array}$} \\
\hline & B & $\begin{array}{l}\text { Std. } \\
\text { Error }\end{array}$ & Beta & & & & \\
\hline (Constant) & 0.542 & 0.225 & & 2.407 & 0.053 & & \\
\hline NDVI & 1.183 & 0.226 & 0.348 & 5.238 & 0.002 & 0.682 & 1.466 \\
\hline LST $\left({ }^{0} \mathrm{C}\right)$ & 0.022 & 0.004 & 0.728 & 5.953 & 0.001 & 0.201 & 4.965 \\
\hline $\begin{array}{l}\text { Elevation } \\
(\mathrm{m})\end{array}$ & 0.000 & 0.000 & $\begin{array}{c}- \\
0.257\end{array}$ & $\begin{array}{r}- \\
1.647\end{array}$ & 0.151 & 0.124 & 8.097 \\
\hline $\begin{array}{l}\text { Aspect } \\
\left(0-360^{0}\right)\end{array}$ & $\begin{array}{c}- \\
7.167 \\
\mathrm{E}- \\
006\end{array}$ & 0.000 & $\begin{array}{c}- \\
0.005\end{array}$ & $\begin{array}{r}- \\
0.054\end{array}$ & 0.959 & 0.321 & 3.116 \\
\hline $\begin{array}{l}\text { Slope } \\
(\%)\end{array}$ & $\begin{array}{c}- \\
0.004\end{array}$ & 0.005 & $\begin{array}{c}- \\
0.073 \\
\end{array}$ & $\begin{array}{r}- \\
0.829 \\
\end{array}$ & 0.439 & 0.390 & 2.563 \\
\hline
\end{tabular}

Table 2. Result of regression analysis

From the assumption (Equation (6)), we developed the model for predicted soil moisture. Equation (8) was used for the development of predicted SMI (PSMI) of the model in this research:

$P S M I=0.348 * N D V I+0.728 * L S T-0.257 *$ Elevation0.005* Aspect $-0.073^{*}$ Slope

\section{RESULTS}

To validate the model, we selected 12 samples from Table 1 (additional 21 points) where ground truth for SM was measured.

There's a significant positive relationship between SMI and PSMI $(p<0.001)$ in the table 3 and figure 8 . The scatter plot of the PSMI from the model and SMI from satellite is shown in Figure 8 with $\left(R^{2}=0.903\right)$ for kastanozems soil.

\begin{tabular}{|l|l|c|c|}
\hline \multicolumn{2}{|c|}{} & Prediction SMI & SMI \\
\hline \multirow{3}{*}{$\begin{array}{l}\text { Prediction } \\
\text { SMI }\end{array}$} & $\begin{array}{l}\text { Pearson } \\
\text { Correlation }\end{array}$ & 1 & $0.951^{* *}$ \\
\cline { 2 - 4 } & Sig. (2-tailed) & & .000 \\
\cline { 2 - 4 } & $\mathrm{N}$ & 33 & 33 \\
\hline \multirow{5}{*}{ SMI } & $\begin{array}{l}\text { Pearson } \\
\text { Correlation }\end{array}$ & $0.951^{* *}$ & 1 \\
\cline { 2 - 4 } & Sig. (2-tailed) & .000 & 33 \\
\cline { 2 - 4 } & $\mathrm{N}$ & 33 & 33 \\
\hline \multirow{2}{*}{$* *$ Correlation is significant at the 0.01 level (2-tailed). } \\
\hline
\end{tabular}

Table 3. Correlations between the PSMI and SMI

Also, there are significant positive relationship between ground truth measurement and PSMI $(\mathrm{p}<0.001)$ in the table 4 and figure 9. The ground measurement data was compared with the PSMI from the model $\left(R^{2}=0.65\right)$ (Figure 9).

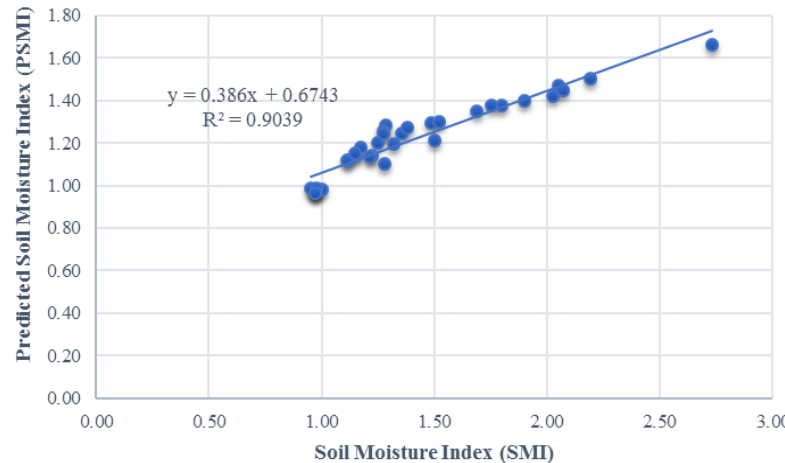

Figure 8. Relationship of SMI from satellite and PSMI

\begin{tabular}{|l|l|r|r|}
\hline \multicolumn{2}{|c|}{ SM (mm) } & \multicolumn{1}{|c|}{ Preciction SMI } \\
\hline \multirow{4}{*}{ SM (mm) } & $\begin{array}{l}\text { Pearson } \\
\text { Correlation }\end{array}$ & 1 & $.806^{* *}$ \\
\cline { 2 - 4 } & Sig. (2-tailed) & & .000 \\
\cline { 2 - 4 } & $\mathrm{N}$ & 33 & 33 \\
\hline \multirow{2}{*}{$\begin{array}{l}\text { Prediction } \\
\text { SMI }\end{array}$} & $\begin{array}{l}\text { Pearson } \\
\text { Correlation }\end{array}$ & $.806^{* *}$ & 1 \\
\cline { 2 - 4 } & Sig. (2-tailed) & .000 & 33 \\
\cline { 2 - 4 } & $\mathrm{N}$ & 33 & \\
\hline \multirow{2}{*}{$* *$. Correlation is significant at the 0.01 level (2-tailed). } \\
\hline
\end{tabular}

Table 4. Correlations between the ground truth measurement and PSMI

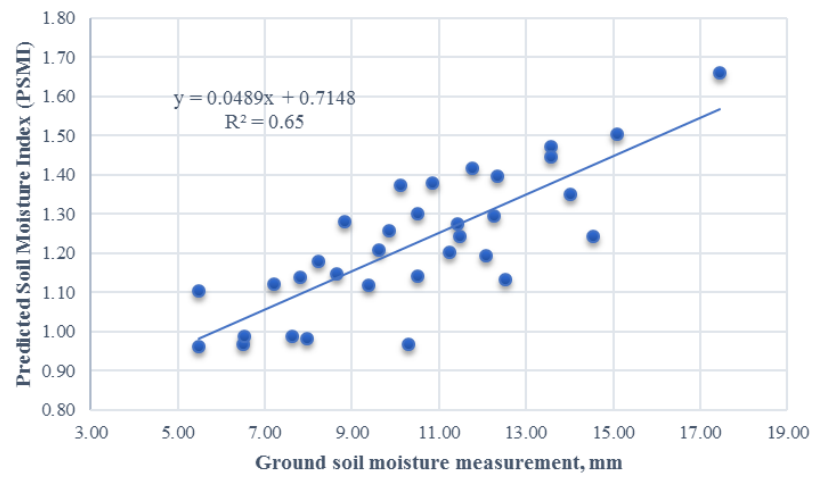

Figure 9. Relationship of ground soil moisture measurement and PSMI

We used the Equation (8) for the estimation of kastanozems soil in the Table 5. This output was compared with ground truth data and shows moisture positive relation. In the table 5, the variables are described in detail. For instance, the soil moisture ground truth measurement, soil moisture index (SMI), normalized difference vegetation index (NDVI), land surface temperature (LST), elevation, aspect, slope and predicted soil moisture index (PSMI).

\begin{tabular}{cccccccc}
\hline $\begin{array}{c}\text { SM ground } \\
\text { truth } \\
\text { measurement } \\
(\mathrm{mm})\end{array}$ & $\begin{array}{c}\text { SMI } \\
\text { from } \\
\text { satellite }\end{array}$ & NDVI & $\begin{array}{c}\text { LST } \\
\left({ }^{\circ} \mathrm{C}\right)\end{array}$ & $\begin{array}{c}\text { Elevation } \\
(\mathrm{m})\end{array}$ & $\begin{array}{c}\text { Aspect } \\
(0- \\
\left.360^{\circ}\right)\end{array}$ & $\begin{array}{c}\text { Slope } \\
(\%)\end{array}$ & PSMI \\
\hline 9.474 & 0.95 & 0.03 & 31.19 & 1072 & 285.95 & 4.77 & 0.99 \\
8.609 & 0.97 & 0.03 & 29.75 & 1070 & 270.00 & 2.62 & 0.97 \\
9.238 & 1.00 & 0.04 & 29.75 & 1071 & 270.00 & 1.97 & 0.98 \\
8.446 & 0.98 & 0.00 & 33.08 & 1181 & 288.43 & 6.22 & 0.97 \\
10.313 & 0.98 & 0.01 & 33.08 & 1188 & 285.95 & 4.77 & 0.99 \\
7.651 & 0.97 & 0.01 & 32.38 & 1173 & 298.61 & 8.22 & 0.96 \\
7.947 & 1.15 & -0.01 & 38.62 & 900 & 185.71 & 6.59 & 1.14
\end{tabular}




\begin{tabular}{|c|c|c|c|c|c|c|c|}
\hline 10.103 & 1.12 & -0.02 & 37.71 & 905 & 185.19 & 3.62 & 1.12 \\
\hline 11.635 & 1.12 & -0.01 & 37.71 & 899 & 18.43 & 7.26 & 1.12 \\
\hline 12.275 & 1.28 & 0.10 & 38.39 & 900 & 263.66 & 2.97 & 1.28 \\
\hline 10.841 & 1.17 & 0.02 & 38.62 & 904 & 236.31 & 4.73 & 1.18 \\
\hline 9.084 & 1.15 & 0.00 & 37.94 & 904 & 243.43 & 2.93 & 1.15 \\
\hline 11.48 & 1.36 & 0.27 & 29.92 & 1072 & 175.10 & 6.71 & 1.24 \\
\hline 12.26 & 1.49 & 0.31 & 29.92 & 1070 & 175.10 & 4.20 & 1.30 \\
\hline 14.01 & 1.69 & 0.38 & 29.92 & 1071 & 210.06 & 11.56 & 1.35 \\
\hline 12.11 & 1.80 & 0.43 & 29.98 & 1194 & 55.89 & 13.56 & 1.37 \\
\hline 13.57 & 2.05 & 0.49 & 29.98 & 1188 & 13.67 & 7.49 & 1.47 \\
\hline 11.75 & 2.03 & 0.45 & 29.98 & 1173 & 58.40 & 11.61 & 1.42 \\
\hline 10.50 & 1.52 & 0.29 & 29.75 & 934 & 130.03 & 5.27 & 1.30 \\
\hline 11.23 & 1.25 & 0.16 & 33.08 & 935 & 147.70 & 9.43 & 1.20 \\
\hline 10.50 & 1.22 & 0.10 & 33.08 & 936 & 147.30 & 6.31 & 1.14 \\
\hline 9.87 & 1.28 & 0.20 & 32.38 & 930 & 73.30 & 3.56 & 1.26 \\
\hline 12.34 & 1.90 & 0.20 & 38.62 & 927 & 161.60 & 1.43 & 1.40 \\
\hline 12.09 & 1.32 & 0.18 & 29.92 & 930 & 158.90 & 0.00 & 1.20 \\
\hline 7.49 & 1.28 & 0.13 & 29.98 & 912 & 145.50 & 9.48 & 1.10 \\
\hline 12.54 & 1.22 & 0.14 & 29.98 & 918 & 171.50 & 3.54 & 1.13 \\
\hline 14.54 & 1.27 & 0.23 & 29.98 & 919 & 185.90 & 3.35 & 1.24 \\
\hline 9.63 & 1.50 & 0.28 & 29.75 & 900 & 63.43 & 27.57 & 1.21 \\
\hline 15.09 & 2.19 & 0.50 & 29.75 & 905 & 210.97 & 16.55 & 1.50 \\
\hline 17.44 & 2.73 & 0.60 & 29.75 & 899 & 177.88 & 8.58 & 1.66 \\
\hline 11.44 & 1.38 & 0.21 & 33.08 & 905 & 24.77 & 8.07 & 1.27 \\
\hline 10.85 & 1.76 & 0.36 & 29.92 & 904 & 10.01 & 9.48 & 1.38 \\
\hline 13.57 & 2.07 & 0.46 & 29.98 & 904 & 8.13 & 21.56 & 1.45 \\
\hline
\end{tabular}

Table 5. Kastanozems soil's measurement in Bornuur soum, 18 20 Sept. 2011

For the test model, Equation (8) was applied to another 25 points in Bornuur (Table 6) and developed soil moisture map (Figure 10). The table 6 shows the additional points with the estimated variables (SMI, LST, Elevation, Aspect, Slope and PSMI).

\begin{tabular}{ccccccccc}
\hline Latitude & Longitude & SMI & $\begin{array}{c}\text { LST } \\
\left({ }^{\circ} \mathrm{C}\right)\end{array}$ & NDVI & $\begin{array}{c}\text { Elevation } \\
(\mathrm{m})\end{array}$ & $\begin{array}{c}\text { Aspect } \\
\left(0-360^{\circ}\right)\end{array}$ & $\begin{array}{c}\text { Slope } \\
(\%)\end{array}$ & PSMI \\
\hline $106^{\circ} 9^{\prime} 12^{\prime \prime}$ & $48^{\circ} 37^{\prime} 43.8^{\prime \prime}$ & 0.9512 & 31.187 & 0.0263 & 1072.0 & 285.945 & 4.774 & 1.023 \\
$106^{\circ} 9^{\prime} 14.6^{\prime \prime}$ & $48^{\circ} 37^{\prime} 45.3^{\prime \prime}$ & 0.9744 & 29.746 & 0.0270 & 1070.0 & 270.000 & 2.623 & 1.002 \\
$106^{\circ} 9^{\prime} 17^{\prime \prime}$ & $48^{\circ} 37^{\prime} 46.7^{\prime \prime}$ & 1.0000 & 29.746 & 0.0380 & 1071.0 & 270.000 & 1.967 & 1.017 \\
$106^{\circ} 6^{\prime} 52.4^{\prime \prime}$ & $48^{\circ} 36^{\prime} 52.6^{\prime \prime}$ & 0.9756 & 33.084 & 0.0000 & 1181.0 & 288.435 & 6.221 & 1.007 \\
$106^{\circ} 6^{\prime} 50.4^{\prime \prime}$ & $48^{\circ} 36^{\prime} 50.4^{\prime \prime}$ & 0.9750 & 33.084 & 0.0130 & 1188.0 & 285.945 & 4.774 & 1.026 \\
$106^{\circ} 6^{\prime} 47.3^{\prime \prime}$ & $48^{\circ} 36^{\prime} 52.6^{\prime \prime}$ & 0.9744 & 32.376 & 0.0133 & 1173.0 & 298.610 & 8.216 & 1.000 \\
$106^{\circ} 16^{\prime} 23.7^{\prime \prime}$ & $48^{\circ} 40^{\prime} 49.1^{\prime \prime}$ & 1.1522 & 38.619 & -0.0093 & 900.0 & 185.711 & 6.590 & 1.172 \\
$106^{\circ} 16^{\prime} 28.4^{\prime \prime}$ & $48^{\circ} 40^{\prime} 49.9^{\prime \prime}$ & 1.1176 & 37.712 & -0.0172 & 905.0 & 185.194 & 3.621 & 1.154 \\
$106^{\circ} 16^{\prime} 32.9^{\prime \prime}$ & $48^{\circ} 40^{\prime} 50.5^{\prime \prime}$ & 1.1154 & 37.712 & -0.0085 & 899.0 & 18.435 & 7.258 & 1.151 \\
$106^{\circ} 16^{\prime} 24.7^{\prime \prime}$ & $48^{\circ} 40^{\prime} 44.6^{\prime \prime}$ & 1.2826 & 38.393 & 0.1028 & 900.0 & 263.660 & 2.969 & 1.314 \\
$106^{\circ} 16^{\prime} 28.8^{\prime \prime}$ & $48^{\circ} 40^{\prime} 45.4^{\prime \prime}$ & 1.1739 & 38.619 & 0.0189 & 904.0 & 236.310 & 4.729 & 1.212 \\
$106^{\circ} 16^{\prime} 31.2^{\prime \prime}$ & $48^{\circ} 40^{\prime} 45.9^{\prime \prime}$ & 1.1489 & 37.940 & 0.0000 & 904.0 & 243.435 & 2.933 & 1.182 \\
$106^{\circ} 16^{\prime} 16.6^{\prime \prime}$ & $48^{\circ} 40^{\prime} 48.5^{\prime \prime}$ & 1.205 & 38.17 & 0.093 & 909 & 184.90 & 11.517 & 1.261 \\
$106^{\circ} 16^{\prime} 44.56^{\prime \prime}$ & $48^{\circ} 40^{\prime} 38.34^{\prime \prime}$ & 1.180 & 36.80 & -0.025 & 895 & 40.43 & 11.629 & 1.095
\end{tabular}

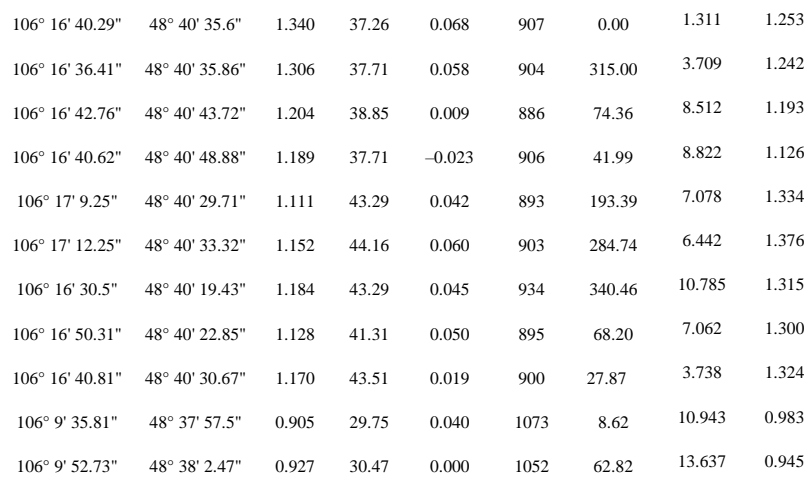

Table 6. SM related drivers in Bornuur soum (additional points)

The results of the PSMI model was compared with the ground SM measurement (traditional) data in Tuv province $\left(r^{2}=0.65\right)$.

The output map from the modelling for kastanozems soil is shown in the Figure 10. The maximum value of PSMI data is 1.56 , the minimum is 0.0 .

We divided PSMI into 3 classes which are low (0.0 1.0), moderate (1.1 1.5) and high (1.6 high). Also, we classified ground truth measurements into 3 similar classes (low, moderate and high). We overlaid randomly our ground truth points on the map and made validation.

In Table 6, we present the matrix evaluation for the validation. The result of PSMI was compared with ground truth measurement (table 7). PSMI result was compared with SM distribution model Erdenetsetseg (1996). The correlation coefficients were respectively $69 \%$ and $66 \%$ respectively.

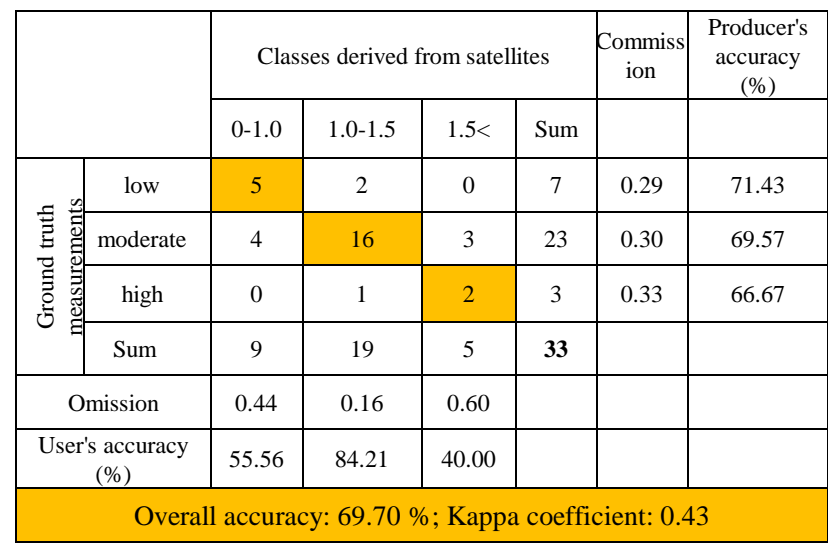

Table 7. Comparison of developed model and ground measurements

The positive results (Figure 8 and Figure 9) should be investigated further, and it needs a more detailed analysis of high-resolution satellite data.

\section{CONCLUSSION}

The long-term moisture will be useful for climate change, drought monitoring and other environment studies. The moisture index was estimated for central part of Mongolia based on MODIS-PET and precipitation station data during the growing season from May - August of 2000-2013. SM is vital for Mongolian agriculture development. SM analysis is needed to assist dry land grain growers to make improved and informed decisions. 


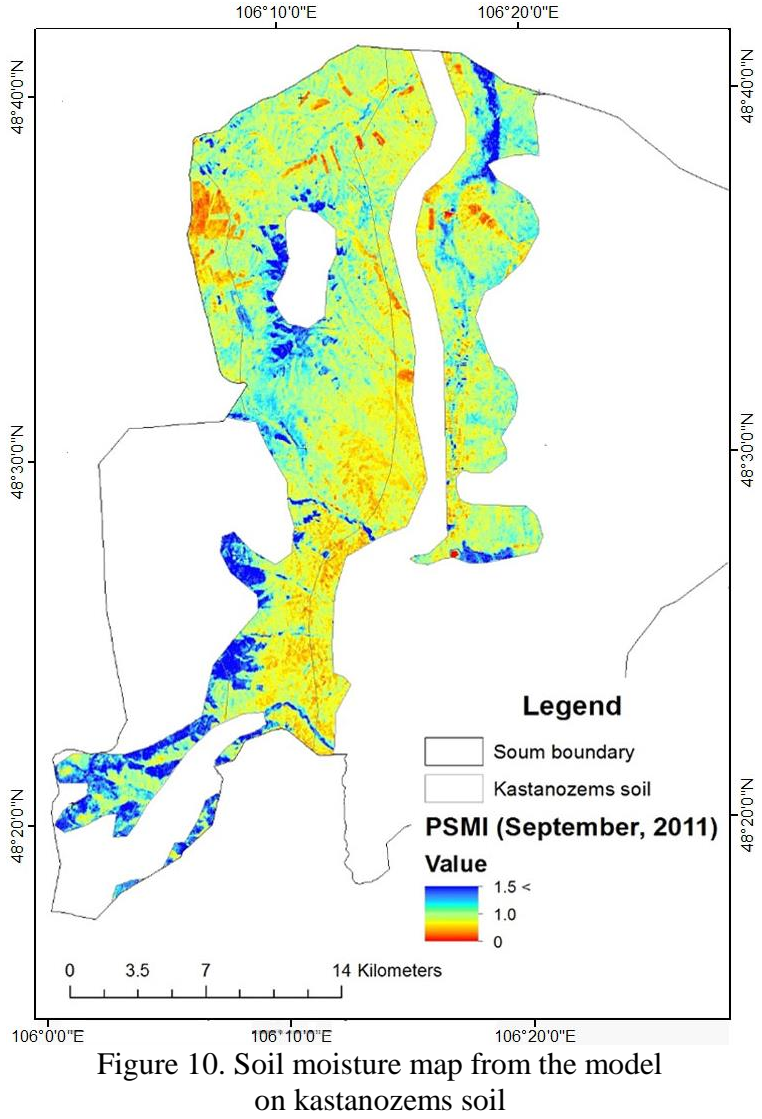

Since less research has been carried out in dry land, policy makers at regional level were not available to make decisions for crop growers in central agricultural areas. This research will aid the crop sector to develop agriculture land, and improve crop quality to expand the Mongolian food demand. SM monitoring also will provide useful insights for pasture land management in other regions of Mongolia. The model developed for this research could be applied for other ecological zones. Only forest steppe region was taken for the analysis. This model (PSMI) can be applied for the same regions using remote sensing methodologies.

In the future, we will apply the integrative model all over the Mongolian landscapes. Since Mongolia has six different landscapes. SM monitoring is important for Mongolian agricultural development. There is a regional plan to develop agricultural land in Mongolian mountain forested areas.

\section{ACKNOWLEDGEMENTS}

We would like to thank Mongolia-Japan Engineering Education Development (MJEED) Project and Department of Geography, Ghent University for their kindly research support. Thanks to the Mongolian Institute of Meteorology and Hydrology for providing meteorological data used in this study.

\section{REFERENCES}

Attorre, F, F Francesconi, N Taleb, P Scholte, A Saed, M Alfo, and F Bruno. 2007. "Will Dragonblood Survive the Next Period of Climate Change Current and Future Potential Distribution of Dracaena Cinnabari (Socotra, Yemen)." Biological Conservation 138 (3-4): 430-439. https://doi.org/10.1016/j.biocon.2007.05.009.
Bayartogtokh, B., B. Oyuntsetseg, B. Badamtsetseg, Y. C. Cho, and H. J. Choi. 2015. Important Plants of East Asia II: Endemic Plant stories. Korea: East Asian Biodiversity Conservation Network (EABCN) \& Korea National Arboretum, Pocheon-si, Gyeonggi-do, Republic of Korea.

Chavez, P. S. Jr. 1996. "Image-based Atmospheric Corrections - Revisited and Improved." Photogrammetric Engineering and Remote Sensing 62(9):1025-1036.

Cornicka S., R. Djebbar, and W. A. Dalgliesh. 2003. "Selecting moisture reference years using a Moisture Index approach." Building and Environment 38(12): 1367-1379. DOI: 10.1016/S0360-1323(03)00139-2.

Dorjgotov, D., 2003. Soils of Mongolia, Publisher: Admon, Ulaanbaatar, Mongolia.

Dupigny-Giroux, L and J. E, Lewis. 1999. "A Moisture index for Surface characterization over Semi-arid area" Journal of Photogrametric engineering Remote sensing, 937-945.

Ghar, M. A., T. Renchin, R. Tateishi, and T. Javzandulam. 2005. "Agricultural Land Monitoring Using a Linear Mixture Model." International Journal of Environmental Studies 62 (2): 227-234. DOI: 10.1080/00207230500034057.

Mohamed, A. A., and R. Kimura. 2014. "Applying the Moisture Availability Index (NTDI) over Vegetated Land in Central Asia: Mongolian Steppe.” Journal of Water Resource and Protection 6(14): 1335-1343. DOI: 10.4236/jwarp.2014.614123.

Lu, H., Koike, T., T. Ohta, K. Tamagawa, H. Fujii, and D. Kuria. 2013. Climate Change Assessment Due to Long Term Soil Moisture Change and Its Applicability Using Satellite Observations. Chapter 14, Publisher: InTech, Rijeka, Croatia, Europian Union.

Tsoozol, M, Batsukh N, Sarantuya G, Erdenesukh S, Enkhbat D, Tsengel T, Jambajamts L., 2008. Mat Surface Heat Balance. Publisher: Master print, Ulaanbaatar, Mongolia.

Sellers, P. J., C. J. Tucker, G. J. Collatz, S. O. Los, C. O. Justice, and D. A. Dazlich. 1994. "A Global $1^{\circ}$ by $1^{\circ}$ NDVI Data Set for Climate Studies. Part 2: The Generation of Global Fields of Terrestrial Biophysical Parameters from the NDVI." International journal of Remote sensing 15 (17): 3493-3518. doi.org/10.1080/01431169408954343.

Verstraeten, W. W., F. Veroustraete, and J. Feyen. 2008. "Assessment of Evapotranspiration and Soil Moisture Content Across Different Scales of Observation." Sensors 8(1): 70-117. DOI: $10.3390 / \mathrm{s} 8010070$

Weng, Q., D. Lu, and J. Schubring. 2004. "Estimation of Land Surface Temperature-Vegetation Abundance Relationship for Urban Heat Island Studies." Remote Sensing of Environment 89(4): 467-483. DOI: 10.1016/j.rse.2003.11.005.

Erdenetsetseg, D., 1996. "Soil moisture distribution and modelling in Mongolia" $\mathrm{PhD}$ thesis, Ulaanbaatar, Mongolia 